\title{
7. PALEOLATITUDE OF THE SOUTHERN KERGUELEN PLATEAU INFERRED FROM THE PALEOMAGNETIC STUDY OF UPPER CRETACEOUS BASALTS ${ }^{1}$
}

\author{
Hiroo Inokuchi² and Franz Heider ${ }^{3}$
}

\begin{abstract}
Paleomagnetic measurements were performed on 106 basalt samples collected from Holes 747C, 748C, 749C, and 750B. Basalt samples were recovered from the southern portion of the Kerguelen Plateau and the transitional zone between the northern and southern plateau in the south central Indian Ocean. The ages of basalts range from 100 to $115 \mathrm{Ma}$. In addition to the preliminary shipboard measurements (Schlich, Wise, et al., 1989), characteristic inclinations of the magnetization were obtained using mainly stepwise thermal demagnetization of the samples. Reliable paleomagnetic results were obtained from three sites (Sites 747, 748, and 749). The paleomagnetic inclinations of Sites 747,748 , and 749 are $-51^{\circ},-63^{\circ}$, and $-62^{\circ}$, respectively. The considerable differences between the paleomagnetic and present inclinations of about $70^{\circ}$ at Sites 747,748 , and 749 indicate that displacement in the direction of the geomagnetic meridian has taken place since formation of the basalt. Shallower paleomagnetic inclinations than the present inclinations at each site imply a southward movement of the sites with respect to the geomagnetic pole. By comparing the apparent polar wander path of Antarctica with the virtual geomagnetic pole (VGP) of the Southern Kerguelen Plateau, we have concluded that no major tectonic movement has taken place between the Kerguelen Plateau and Antarctica since formation of the basalt (i.e., 100-115 Ma). The angular dispersion of the VGP for the Kerguelen Plateau is calculated as $17^{\circ}$.
\end{abstract}

\section{INTRODUCTION}

The Kerguelen Plateau is a broad topographic high in the south central Indian Ocean. The plateau stretches approximately $2300 \mathrm{~km}$ between $46^{\circ} \mathrm{S}$ and $64^{\circ} \mathrm{S}$ from the Antarctic continental margin in a northwest-trending direction. The feature is between 200 and $600 \mathrm{~km}$ wide and stands $2-4 \mathrm{~km}$ above the adjacent oceanic basins (Schlich, Wise, et al., 1989, pp. 7-23). This large plateau is considered to be important for the study of the history of the Indian Ocean. One of the objectives of Ocean Drilling Program (ODP) Leg 120 was to study the tectonic history of the Kerguelen Plateau. Determining the paleolatitude of the plateau provides one key to solve the tectonic history.

The Kerguelen Plateau has been divided into two distinct domains (Schlich, 1975; Houtz et al., 1977). Basalt samples were recovered from the southern portion of the plateau (Sites 748,749 , and 750) and the transitional zone between the northern and southern plateaus (Site 747). The ages of the basalts are $100 \mathrm{~m} . \mathrm{y}$. (Site 748) and between 80 and $115 \mathrm{~m} . \mathrm{y}$. (Sites 747, 749, and 750), as determined radiometrically with the $\mathrm{K} / \mathrm{Ar}$ method (Whitechurch et al., this volume) or between 100 and $115 \mathrm{~m} . \mathrm{y}$. for the four sites, as concluded from paleontologic data (Schlich, Wise, et al., 1989, p. 23, fig. 4). The paleomagnetic results from these Cretaceous rocks are presented in this paper. The rock magnetic properties of these rocks are reported by Heider et al. (this volume).

Preliminary paleomagnetic results from basement rocks were obtained during Leg 120 (Schlich, Wise, et al., 1989). Shipboard measurements were conducted on two to nine

\footnotetext{
${ }^{1}$ Wise, S. W., Jr., Schlich, R., et al., 1992. Proc. ODP, Sci. Results, 120: College Station, TX (Ocean Drilling Program).

${ }^{2}$ Department of Earth Sciences, Faculty of Science, Kobe University, Kobe 657, Japan (current address: Marine Biological Station, Faculty of Science, Kobe University, Iwaya 2746, Awaji, Tsuna, Hyogo 656-24, Japan).

${ }^{3}$ Geophysics Laboratory, Department of Physics, University of Toronto, Toronto, Ontario, M5S 1A7, Canada (current address: Institut für Allgemeine und Angewandte Geophysik, Ludwig-Maximilians-Universität, Theresienstrasse 41, 8000 München 2, Federal Republic of Germany).
}

samples for the different sites. Progressive alternating field (AF) demagnetization was mainly used on board the ship. The purpose of the land-based study was to increase the number of measurements obtained after thermal demagnetization. More reliable paleomagnetic latitude data from the Late Cretaceous basement rocks of the Kerguelen Plateau will be presented synthesizing the shore-based and shipboard paleomagnetic measurements. These paleolatitudes will be discussed in relation to the paleoposition of Antarctica.

\section{SAMPLES AND MEASUREMENTS}

Paleomagnetic studies were performed on 106 basalt samples collected from Holes 747C, 748C, 749C, and 750B. Site $747\left(54^{\circ} 48.7^{\prime} \mathrm{S}, 76^{\circ} 47.6^{\prime} \mathrm{E}\right.$; water depth, $\left.1697 \mathrm{~m}\right)$ lies in the transition zone between the northern and southern parts of the Kerguelen Plateau. The basement rocks that form approximately 15 separate basalt units were recovered between 296.6 and $350.5 \mathrm{~m}$ below seafloor (mbsf) and were named Unit V (Schlich, Wise, et al., 1989, pp. 89-156). We collected 31 samples from 13 flow units. Site $748\left(58^{\circ} 26.5^{\prime} \mathrm{S}, 78^{\circ} 58.9^{\prime} \mathrm{E}\right.$; water depth, $1290 \mathrm{~m}$ ) is located on the Southern Kerguelen Plateau in the western part of the Raggatt Basin, east of the Banzare Bank (Schlich, Wise, et al., 1989, pp. 157-235). Seven samples were collected from the basalt flows recovered between 898.8 and 902.2 mbsf (Subunit IVA). Site 749 $\left(58^{\circ} 43.0^{\prime} \mathrm{S}, 76^{\circ} 24.5^{\prime} \mathrm{E}\right.$; water depth, $\left.1069.5 \mathrm{~m}\right)$ is located on the western flank of the Banzare Bank on the Southern Kerguelen Plateau. The $23.1 \mathrm{~m}$ of recovered basalt consist of five flows and one dyke between 202 and 249.5 mbsf (Unit III; Schlich, Wise, et al., 1989, pp. 237-275). We collected 37 samples from the 5 flows. Site $750\left(57^{\circ} 35.5^{\prime} \mathrm{S}, 81^{\circ} 14.4^{\prime} \mathrm{E}\right.$; water depth, 2030.5 $\mathrm{m}$ ) is located on the Southern Kerguelen Plateau in the eastern part of the Raggatt Basin, west of the Labuan Basin. At least four basalt flows (Unit V) were recovered between 675.5 and 709.7 mbsf (Schlich, Wise, et al., 1989, pp. 277-337), and 33 specimens were sampled for paleomagnetic measurements.

All basalt samples were taken from the sampling half of the core, and cylindrical samples $(2.5 \mathrm{~cm}$ in diameter and $2 \mathrm{~cm}$ in height) were cut. Before drilling the specimen, an arrow 
pointing in the upcore direction was marked with a diamond pen.

Paleomagnetic measurements were conducted on JOIDES Resolution and at Kobe University. Remanent magnetizations were measured with a spinner magnetometer. During the cruise, 8, 2, 7, and 6 samples from Sites 747, 748, 749, and 750, respectively, were stepwise AF demagnetized up to $80 \mathrm{mT}$, or until the intensity of magnetization had been reduced to $5 \%$ of the original intensity. One sample from each site (Samples 120-747C-12R-4, 3-5 cm; 120-748C-79R-6, 50-52 cm; $120-$ 749C-16R-6, 84-86 cm; and 120-750B-15R-4, 126-128 cm) was thermally demagnetized up to $600^{\circ} \mathrm{C}$ on the ship. In most cases, results from AF and thermal demagnetization agree well at each site. Stepwise thermal demagnetization up to the Curie temperature was chosen for the remaining samples for the shore-based measurements.

The inclination of the characteristic magnetization of a sample was determined from a straight line that passes through three or more data points and the origin on an orthogonal vector plot (Zijderveld diagram; Zijderveld, 1967). The declinations of all samples are arbitrary because the basement cores were recovered with a rotary core barrel (RCB) corer. Therefore, the cores were unoriented with respect to azimuth. Inclination, intensity of natural remanent magnetization (NRM), and the temperature or AF interval that was used for determination of the characteristic direction are shown in Table 1.

The mean inclination of each flow and each site was determined using the characteristic inclinations of the samples and the mean inclinations of the flows, respectively. For calculating the mean inclination of each flow or site, special statistics had to be used because the rocks had only inclination values. The algorithm developed by Kono (1980) was employed in the computation of mean inclinations and $95 \%$ confidence limits $\left(\alpha_{95}\right)$. From the mean inclination of each site, the equivalent magnetic paleolatitude was calculated under the assumption of an axial geocentric dipole field.

\section{RESULTS AND DISCUSSION}

\section{Site 747}

Eight samples were AF demagnetized, and 23 samples were thermally demagnetized. There are two types of intensity decay curves during stepwise thermal demagnetization. Sample 120-747C-12R-4, 27-29 cm, has two magnetic phases (Fig. 1). Stable inclinations of this sample were obtained from a rather high-temperature component (i.e., $500^{\circ}-560^{\circ} \mathrm{C}$; Fig. 1). Sample $120-747$ C-15R-3, 127-129 cm, has little indication of a second magnetic phase, and its stable component is obtained from a rather wide temperature interval (i.e., $200^{\circ}-560^{\circ} \mathrm{C}$; Fig. 2). Characteristic inclinations from all samples with both types of intensity decay curves were taken for the calculation of mean inclination. The high-temperature component (Fig. 1) suggests the presence of a low-Ti titanomagnetite. Low-Ti titanomagnetites with exsolved ilmenite lamellae and/or lowtemperature oxidized titanomaghemite were found from rock magnetic investigations of the basalts from Site 747 (Heider et al., this volume). The median destructive fields (MDF) for eight samples using AF demagnetization range from 11 to 32 $\mathrm{mT}$.

All samples from Site 747 have a stable component of remanence during both stepwise thermal and AF demagnetization. The rather high MDFs and the existence of the magnetite with ilmenite lamellae formed by high-temperature oxidation suggests that characteristic inclinations at this site are from primary magnetization acquired at the age of the basalt flow
Table 1. Paleomagnetic results of basalts from the Kerguelen Plateau (Sites 747, 748, 749, and 750).

\begin{tabular}{|c|c|c|c|c|}
\hline \multirow{2}{*}{$\begin{array}{l}\begin{array}{c}\text { Core, section, } \\
\text { interval }(\mathrm{cm})\end{array} \\
120-747 \mathrm{C} \text { - }\end{array}$} & \multirow[t]{2}{*}{ Inc. $\left({ }^{\circ}\right)$} & \multirow[t]{2}{*}{$\begin{array}{c}\mathrm{M}_{\mathrm{o}} \\
(\mathrm{A} / \mathrm{m})\end{array}$} & \multicolumn{2}{|c|}{$\begin{array}{c}\text { Demag range } \\
\text { (degrees or } \mathrm{mT} \text { ) }\end{array}$} \\
\hline & & & & \\
\hline $11 \mathrm{R}-1,42-44$ & -57 & 2.91 & $\mathrm{AF}$ & $3-25$ \\
\hline $\begin{array}{l}11 \mathrm{R}-2,19-21 \\
11 \mathrm{R}-2,94-95 \\
11 \mathrm{R}-2,136-138 \\
11 \mathrm{R}-3,28-30 \\
11 \mathrm{R}-3,94-96\end{array}$ & $\begin{array}{l}-48 \\
-50 \\
-52 \\
-43 \\
-55\end{array}$ & $\begin{array}{l}2.55 \\
5.06 \\
1.79 \\
3.10 \\
3.42\end{array}$ & $\begin{array}{l}\mathrm{TH} \\
\mathrm{AF} \\
\mathrm{AF} \\
\mathrm{AF} \\
\mathrm{AF}\end{array}$ & $\begin{array}{c}450-560 \\
5-60 \\
10-25 \\
5-20 \\
15-50\end{array}$ \\
\hline Mean $\quad N=5$ & -50 & \multicolumn{2}{|c|}{$\alpha_{95}=5.5^{\circ}$} & $k=195$ \\
\hline 12R-1, 47-49 & -59 & 8.62 & $\mathrm{TH}$ & $500-560$ \\
\hline $\begin{array}{l}12 \mathrm{R}-2,61-63 \\
12 \mathrm{R}-2,99-101 \\
12 \mathrm{R}-2,126-128 \\
12 \mathrm{R}-3,84-86 \\
12 \mathrm{R}-3,137-139 \\
12 \mathrm{R}-4,3-5\end{array}$ & $\begin{array}{l}-52 \\
-52 \\
-54 \\
-54 \\
-53 \\
-54\end{array}$ & $\begin{array}{l}0.63 \\
0.29 \\
0.23 \\
2.87 \\
3.20 \\
2.71 \\
\end{array}$ & $\begin{array}{l}\text { TH } \\
\text { TH } \\
\text { TH } \\
\text { TH } \\
\text { TH } \\
\text { AF }\end{array}$ & $\begin{array}{c}200-530 \\
400-560 \\
200-500 \\
100-570 \\
200-560 \\
5-15 \\
\end{array}$ \\
\hline Mean $\quad N=6$ & -53 & \multicolumn{2}{|c|}{$\alpha_{95}=1.0^{\circ}$} & $k=4043$ \\
\hline $12 \mathrm{R}-4,27-29$ & -49 & 3.40 & TH & $200-560$ \\
\hline $\begin{array}{l}13 R-1,2-4 \\
13 R-1,27-29 \\
13 R-1,98-100\end{array}$ & $\begin{array}{l}-46 \\
-53 \\
-53 \\
\end{array}$ & $\begin{array}{l}2.90 \\
2.44 \\
2.23\end{array}$ & $\begin{array}{l}\text { TH } \\
\text { TH } \\
\text { TH }\end{array}$ & $\begin{array}{l}300-560 \\
350-500 \\
200-600 \\
\end{array}$ \\
\hline Mean $\quad N=3$ & -51 & \multicolumn{2}{|c|}{$\alpha_{95}=7.3^{\circ}$} & $k=286$ \\
\hline $13 R-3,35-37$ & -41 & 2.70 & TH & $400-600$ \\
\hline $\begin{array}{l}14 \mathrm{R}-1,38-40 \\
14 \mathrm{R}-1,113-115\end{array}$ & $\begin{array}{l}-18 \\
-42 \\
\end{array}$ & $\begin{array}{l}5.49 \\
1.89 \\
\end{array}$ & $\begin{array}{l}\text { TH } \\
\text { TH }\end{array}$ & $\begin{array}{l}100-560 \\
500-600 \\
\end{array}$ \\
\hline Mean $\quad N=2$ & -31 & & & \\
\hline $\begin{array}{l}15 \mathrm{R}-1,32-34 \\
15 \mathrm{R}-1,71-73\end{array}$ & $\begin{array}{l}-40 \\
-38\end{array}$ & $\begin{array}{l}1.42 \\
1.43\end{array}$ & $\begin{array}{l}\text { AF } \\
\text { TH }\end{array}$ & $\begin{array}{c}20-80 \\
350-560\end{array}$ \\
\hline Mean $\quad N=2$ & & -39 & & \\
\hline $\begin{array}{l}15 R-2,86-88 \\
15 R-2,131-133\end{array}$ & $\begin{array}{l}-71 \\
-71 \\
\end{array}$ & $\begin{array}{l}4.79 \\
2.16 \\
\end{array}$ & $\begin{array}{l}\mathrm{AF} \\
\mathrm{TH}\end{array}$ & $\begin{array}{c}20-80 \\
200-560 \\
\end{array}$ \\
\hline Mean $\quad N=2$ & & -71 & & \\
\hline $\begin{array}{l}15 \mathrm{R}-3,127-129 \\
15 \mathrm{R}-4,53-55\end{array}$ & $\begin{array}{l}-46 \\
-62 \\
\end{array}$ & $\begin{array}{l}1.83 \\
2.68 \\
\end{array}$ & $\begin{array}{l}\text { TH } \\
\text { TH }\end{array}$ & $\begin{array}{l}200-560 \\
450-530 \\
\end{array}$ \\
\hline Mean $\quad N=2$ & & -55 & & \\
\hline $\begin{array}{l}16 \mathrm{R}-2,74-76 \\
16 \mathrm{R}-2,98-100\end{array}$ & $\begin{array}{l}-46 \\
-52 \\
\end{array}$ & $\begin{array}{l}1.20 \\
1.35 \\
\end{array}$ & $\begin{array}{l}\text { TH } \\
\text { TH }\end{array}$ & $\begin{array}{l}300-560 \\
200-530 \\
\end{array}$ \\
\hline Mean $\quad N=2$ & & -49 & & \\
\hline $\begin{array}{l}16 \mathrm{R}-4,61-63 \\
16 \mathrm{R}-5,13-15 \\
16 \mathrm{R}-5,46-48 \\
\end{array}$ & $\begin{array}{l}-37 \\
-38 \\
-38 \\
\end{array}$ & $\begin{array}{l}2.12 \\
0.94 \\
1.02 \\
\end{array}$ & $\begin{array}{l}\text { TH } \\
\text { TH } \\
\text { TH }\end{array}$ & $\begin{array}{l}100-530 \\
450-600 \\
400-600 \\
\end{array}$ \\
\hline Mean $\quad N=3$ & -38 & $\alpha_{95}$ & $1.0^{\circ}$ & $k=14704$ \\
\hline \multicolumn{5}{|l|}{$120-748 \mathrm{C}$ - } \\
\hline $\begin{array}{l}79 \mathrm{R}-6,22-24 \\
79 \mathrm{R}-6,50-52 \\
79 \mathrm{R}-6,73-75 \\
79 \mathrm{R}-6,121-123 \\
79 \mathrm{R}-7,3-5 \\
79 \mathrm{R}-7,45-46 \\
79 \mathrm{R}-\mathrm{CC}, 15-17\end{array}$ & $\begin{array}{l}-61 \\
-68 \\
-63 \\
-70 \\
-62 \\
-68 \\
-62 \\
\end{array}$ & $\begin{array}{l}11.30 \\
17.96 \\
15.00 \\
10.35 \\
16.50 \\
9.69 \\
8.89\end{array}$ & $\begin{array}{l}\text { TH } \\
\text { TH } \\
\text { TH } \\
\text { AF } \\
\text { TH } \\
\text { AF } \\
\text { TH }\end{array}$ & $\begin{array}{c}400-560 \\
400-500 \\
400-530 \\
10-20 \\
400-500 \\
15-35 \\
400-530 \\
\end{array}$ \\
\hline $\begin{array}{ll}\text { Mean } & N=7 \\
\text { Mean } & N=5 \\
\text { (only thermal der } & \\
\end{array}$ & $\begin{array}{c}-65 \\
-63 \\
\text { agnetizatio }\end{array}$ & $\begin{array}{l}\alpha_{95} \\
\alpha_{95}\end{array}$ & $\begin{array}{l}3.5^{\circ} \\
3.1^{\circ}\end{array}$ & $\begin{array}{l}k=295 \\
k=596\end{array}$ \\
\hline \multicolumn{5}{|l|}{$120-749 \mathrm{C}$} \\
\hline $\begin{array}{l}12 \mathrm{R}-1,135-137 \\
12 \mathrm{R}-2,15-17 \\
12 \mathrm{R}-2,82-84 \\
12 \mathrm{R}-2,99-101 \\
12 \mathrm{R}-3,55-57\end{array}$ & $\begin{array}{l}-62 \\
-62 \\
-66 \\
-69 \\
-63 \\
\end{array}$ & $\begin{array}{l}3.20 \\
4.05 \\
7.31 \\
4.24 \\
6.51 \\
\end{array}$ & $\begin{array}{l}\text { TH } \\
\text { TH } \\
\text { TH } \\
\text { AF } \\
\text { TH }\end{array}$ & $\begin{array}{c}200-600 \\
100-560 \\
400-600 \\
5-50 \\
400-600 \\
\end{array}$ \\
\hline Mean $\quad N=5$ & -65 & \multicolumn{2}{|c|}{$\alpha_{95}=3.5^{\circ}$} & $k=473$ \\
\hline
\end{tabular}


Table 1 (continued).

\begin{tabular}{|c|c|c|c|c|}
\hline \multirow{2}{*}{$\begin{array}{c}\begin{array}{c}\text { Core, section, } \\
\text { interval }(\mathrm{cm})\end{array} \\
12 \mathrm{R}-4,7-9\end{array}$} & \multirow{2}{*}{$\frac{\text { Inc. }\left({ }^{\circ}\right)}{-63}$} & \multirow{2}{*}{$\begin{array}{c}\begin{array}{c}\mathrm{M}_{\mathrm{o}} \\
(\mathrm{A} / \mathrm{m})\end{array} \\
2.35\end{array}$} & \multicolumn{2}{|c|}{$\begin{array}{c}\text { Demag range } \\
\text { (degrees or } \mathrm{mT} \text { ) }\end{array}$} \\
\hline & & & TH & $400-600$ \\
\hline $12 R-4,134-136$ & -62 & 1.94 & TH & $400-600$ \\
\hline $12 \mathrm{R}-5,3-5$ & -66 & 10.90 & TH & $450-530$ \\
\hline $12 \mathrm{R}-5,41-43$ & -68 & 3.83 & $\mathrm{TH}$ & $450-560$ \\
\hline $12 \mathrm{R}-5,45-47$ & -69 & 2.77 & $\mathrm{AF}$ & $5-30$ \\
\hline Mean $\quad N=5$ & -66 & \multicolumn{2}{|c|}{$\alpha_{95}=53.7^{\circ}$} & $k=5435$ \\
\hline $15 \mathrm{R}-1,44-46$ & -64 & 1.07 & TH & $200-500$ \\
\hline $15 \mathrm{R}-1,121-123$ & -52 & 3.32 & $\mathrm{AF}$ & $15-40$ \\
\hline $15 \mathrm{R}-2,27-29$ & -58 & 4.08 & TH & $300-560$ \\
\hline $15 \mathrm{R}-2,85-87$ & -40 & 12.70 & $\mathrm{TH}$ & $450-530$ \\
\hline 15R-2, $130-130$ & -58 & 4.14 & $\mathrm{TH}$ & $450-530$ \\
\hline $15 \mathrm{R}-3,19-21$ & -63 & 3.18 & $\mathrm{TH}$ & $200-530$ \\
\hline $15 R-4,13-15$ & -59 & 5.60 & TH & $200-530$ \\
\hline $15 R-4,87-89$ & -60 & 4.41 & TH & $200-530$ \\
\hline $15 R-5,73-75$ & - & 1.31 & AF & \\
\hline Mean $\quad N=8$ & -58 & \multicolumn{2}{|c|}{$\alpha_{95}=8.0^{\circ}$} & $k=549$ \\
\hline $15 R-5,140-142$ & -60 & 12.50 & TH & $400-530$ \\
\hline $15 \mathrm{R}-6,57-59$ & -58 & 4.38 & TH & $400-560$ \\
\hline $15 \mathrm{R}-6,113-115$ & -63 & 13.10 & TH & $100-530$ \\
\hline 15R-6, 124-126 & -58 & 5.46 & AF & $20-50$ \\
\hline $15 \mathrm{R}-7,3-5$ & -60 & 7.20 & TH & $200-500$ \\
\hline $16 \mathrm{R}-1,24-26$ & -63 & 12.70 & TH & $200-530$ \\
\hline Mean $\quad N=6$ & -60 & \multicolumn{2}{|c|}{$\alpha_{95}=52.4^{\circ}$} & $k=5789$ \\
\hline 16R-1, 139-141 & -61 & 6.76 & $\mathrm{TH}$ & $200-560$ \\
\hline $16 \mathrm{R}-2,134-136$ & -62 & 2.62 & TH & $200-600$ \\
\hline $16 \mathrm{R}-3,134-136$ & -63 & 8.54 & TH & $200-530$ \\
\hline $16 \mathrm{R}-4,132-134$ & -62 & 11.10 & TH & $400-560$ \\
\hline $16 \mathrm{R}-5,32-34$ & -63 & 10.10 & $\mathrm{TH}$ & $200-560$ \\
\hline $16 R-5,111-113$ & -65 & 3.63 & AF & $30-50$ \\
\hline $16 \mathrm{R}-5,119-121$ & -64 & 12.90 & TH & $100-600$ \\
\hline $16 \mathrm{R}-6,9-11$ & -64 & 13.90 & TH & $200-560$ \\
\hline $16 \mathrm{R}-6,84-86$ & -65 & 12.27 & TH & $60-590$ \\
\hline 16R-6, 107-109 & -64 & 7.53 & $\mathrm{AF}$ & $20-60$ \\
\hline $16 \mathrm{R}-7,18-20$ & -62 & 8.88 & TH & $200-560$ \\
\hline $16 \mathrm{R}-7,61-63$ & -65 & 9.24 & TH & $200-560$ \\
\hline Mean $\quad N=12$ & -63 & \multicolumn{2}{|c|}{$\alpha_{95}=1.0^{\circ}$} & $k=1890$ \\
\hline \multicolumn{5}{|l|}{$120-750 \mathrm{~B}-$} \\
\hline $15 R-1,62-64$ & -70 & 3.44 & TH & $200-560$ \\
\hline $15 R-2,62-64$ & -74 & 1.41 & TH & $200-560$ \\
\hline $15 \mathrm{R}-2,78-80$ & -76 & 0.76 & $\mathrm{AF}$ & $10-40$ \\
\hline $15 \mathrm{R}-2,101-103$ & -74 & 0.90 & TH & $200-560$ \\
\hline $15 \mathrm{R}-3,83-85$ & -75 & 1.38 & TH & $200-560$ \\
\hline $15 \mathrm{R}-3,98-100$ & -76 & 1.33 & TH & $300-560$ \\
\hline $15 R-4,25-27$ & -78 & 0.99 & TH & $200-560$ \\
\hline $15 \mathrm{R}-4,57-59$ & -77 & 1.29 & TH & $200-560$ \\
\hline $15 R-4,126-128$ & -78 & 1.70 & $\mathrm{TH}$ & $60-540$ \\
\hline $15 \mathrm{R}-5,22-24$ & - & 1.85 & TH & \\
\hline $15 R-5,114-116$ & - & 2.45 & TH & \\
\hline $15 \mathrm{R}-6,80-82$ & - & 2.20 & TH & \\
\hline $15 \mathrm{R}-7,17-19$ & - & 1.57 & TH & \\
\hline $16 \mathrm{R}-1,31-33$ & - & 2.55 & TH & \\
\hline $16 \mathrm{R}-1,140-142$ & - & 2.74 & TH & \\
\hline $16 \mathrm{R}-2,13-15$ & -69 & 2.46 & TH & $200-450$ \\
\hline $16 \mathrm{R}-2,129-131$ & -71 & 3.44 & TH & $250-400$ \\
\hline $16 \mathrm{R}-3,68-70$ & - & 3.38 & TH & \\
\hline $16 \mathrm{R}-3,134-136$ & -73 & 2.21 & $\mathrm{AF}$ & $20-30$ \\
\hline $16 \mathrm{R}-4,56-58$ & -73 & 2.62 & TH & $200-500$ \\
\hline $16 \mathrm{R}-4,77-79$ & -72 & 2.84 & TH & $200-450$ \\
\hline $16 \mathrm{R}-4,98-100$ & -77 & 0.83 & $\mathrm{AF}$ & $5-15$ \\
\hline $16 \mathrm{R}-5,130-132$ & - & 2.11 & TH & \\
\hline 16R-6, 16-18 & - & 3.09 & $\mathrm{TH}$ & \\
\hline $16 \mathrm{R}-6,110-112$ & - & 4.77 & TH & \\
\hline $16 \mathrm{R}-7,44-46$ & -72 & 5.69 & $\mathrm{TH}$ & $200-500$ \\
\hline 16R-7, 104-106 & -70 & 7.15 & TH & $200-500$ \\
\hline $16 \mathrm{R}-8,29-31$ & -70 & 8.03 & TH & $200-530$ \\
\hline $16 \mathrm{R}-8,34-36$ & -71 & 2.77 & $\mathrm{AF}$ & $5-50$ \\
\hline Mean $\quad N=19$ & -74 & \multicolumn{2}{|c|}{$\alpha_{95}=1.7^{\circ}$} & $k=410$ \\
\hline $17 \mathrm{R}-1,49-51$ & -71 & 2.25 & $\mathrm{AF}$ & $5-20$ \\
\hline $17 \mathrm{R}-2,86-88$ & -69 & 2.95 & $\mathrm{AF}$ & $5-20$ \\
\hline $17 \mathrm{R}-2,105-107$ & - & 2.17 & $\mathrm{TH}$ & \\
\hline $17 \mathrm{R}-3,9-11$ & -66 & 2.95 & TH & $400-560$ \\
\hline
\end{tabular}

Table 1 (continued).

\begin{tabular}{|c|c|c|c|c|c|}
\hline \multicolumn{2}{|c|}{$\begin{array}{l}\text { Core, section, } \\
\text { interval }(\mathrm{cm})\end{array}$} & \multirow{2}{*}{ 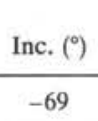 } & \multirow{2}{*}{$\frac{\begin{array}{c}\mathrm{M}_{\mathrm{o}} \\
(\mathrm{A} / \mathrm{m})\end{array}}{\alpha_{95}}$} & \multicolumn{2}{|c|}{$\begin{array}{c}\text { Demag range } \\
\text { (degrees or } \mathrm{mT} \text { ) }\end{array}$} \\
\hline Mean & $N=3$ & & & & $k=759$ \\
\hline \multicolumn{6}{|c|}{$\begin{array}{l}\text { Note: Inc. = characteristic inclination determined from stepwise } \\
\text { demagnetization; } M_{\mathrm{o}}=\mathrm{NRM} \text { intensity; demag = demagneti- } \\
\text { zation by either alternating field }(\mathrm{AF}) \text { or thermal }(\mathrm{TH}) \text { methods } \\
\text { was used; range }=\text { characteristic inclination is determined } \\
\text { from the component in this range during demagnetization. The } \\
\text { thick horizontal lines represent boundaries between basalt } \\
\text { flows. The mean inclination of each flow with } 95 \% \text { confidence } \\
\text { limit }\left(\alpha_{95}\right) \text { and precision parameter } k \text { were calculated using } \\
\text { Kono's }(1980) \text { statistics and represented below the thin line. }\end{array}$} \\
\hline
\end{tabular}

formation. Marshall and Cox (1972) and Johnson and Merrill (1974) have reported that remanent magnetizations do not change their directions much during both single-phase oxidation and low-temperature oxidation on the ocean floor. The NRM directions can be considered useful for paleomagnetism if the high-temperature oxidation happened before the basalt flows cooled. However, the magnetic directions are not very stable during thermal demagnetization at temperatures below $300^{\circ} \mathrm{C}$. Characteristic inclinations from the same flow agree well with each other, as shown in Table 1. The mean inclination of each flow and the $95 \%$ confidence limits are shown in Table 1 . The mean inclination of 13 flows at Site 747 is $-51^{\circ}$, with an error of $7.3^{\circ}$ at the $95 \%$ confidence limit. An inclination of $-51^{\circ}$ is equivalent to a magnetic paleolatitude of $32^{\circ} \mathrm{S}$ and is significantly different from the present inclination of $-71^{\circ}$.

\section{Site $\mathbf{7 4 8}$}

Two samples were AF demagnetized, and five samples were thermally demagnetized at Site 748 . All samples show the two magnetic phases in the stepwise thermal demagnetization. Sample $120-748 \mathrm{C}-79 \mathrm{R}-7,3-5 \mathrm{~cm}$, is shown as a representative example in Figure 3. Stable inclinations for these samples were obtained from the temperature interval above $400^{\circ} \mathrm{C}$. Characteristic inclinations for all thermally demagnetized samples have unblocking temperatures above $400^{\circ} \mathrm{C}$. The intensity ratio of high- to low-temperature phases at Site 748 is relatively small compared with the ratio determined for Site 747. This agrees with the dominant magnetic carrier being titanomaghemite, as found from the rock magnetic investigation (Heider et al., this volume). The MDFs of the two AF demagnetized samples are 8 and $13 \mathrm{mT}$.

All samples from Site 748 have a stable component of remanence during both stepwise thermal demagnetization above $400^{\circ} \mathrm{C}$ and $\mathrm{AF}$ demagnetization. The magnetization of the samples from this site is considered unstable because of the low MDFs and the low-intensity percentage of the higher temperature component. Only the high-temperature phase may have a primary component acquired at the age of the basalt flow formation because the magnetic directions are not very stable during thermal demagnetization below $400^{\circ} \mathrm{C}$. Characteristic inclinations obtained from AF demagnetization are slightly steeper than those obtainted from thermal demagnetization, as shown in Table 1 . The characteristic inclination values $\left(69^{\circ}\right)$ after AF demagnetization are quite close to the present field inclination $\left(-73^{\circ}\right)$.

The mean inclination calculated from five inclination values obtained by thermal demagnetization will be considered in the following. The low MDFs and the present field direction in Samples 120-748C-79R-6, 121-123 cm, and -79R-7, 45-46 cm, indicate a secondary overprint that cannot be removed by $\mathrm{AF}$ demagnetization. Samples were taken from only one flow at this site. The short-term secular variation of the Earth's 

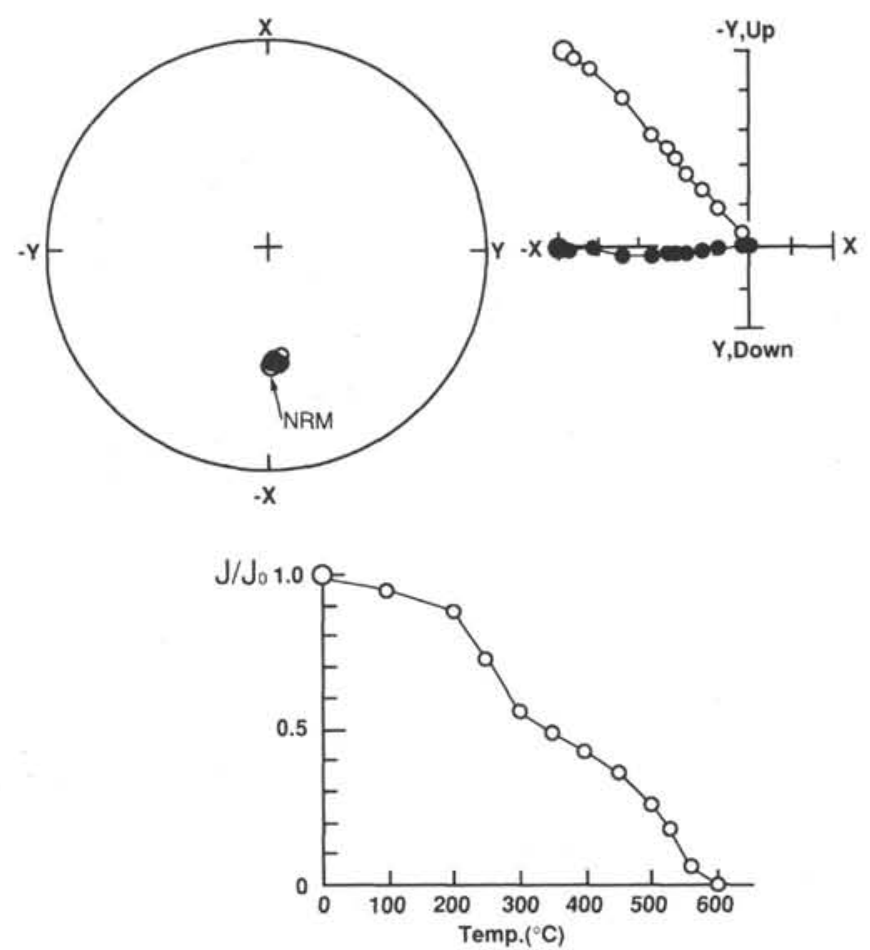

Figure 1. Thermal demagnetization of Sample 120-747C-12R-4, 27-29 $\mathrm{cm}$. Two magnetic phases are shown in the intensity decay curve. Change in direction is shown in an equal area projection (left) and in orthogonal vector projections (right). Solid and open circles represent horizontal ( $\mathrm{X}$ and $\mathrm{Y}$ ) and vertical (upward-downward and $\mathrm{X}$ ) components of magnetization, respectively. Declinations are arbitrary. Normalized intensity decay is plotted vs. temperature of thermal demagnetization (below).

magnetic field is not averaged out in paleomagnetic data from a small number of rock units, and such data are not representative of the long-term dipole field. The mean inclination of this flow will be treated as the characteristic inclination of Site 748. The mean inclination from thermal demagnetization of the flow is $-63^{\circ}$, with an error of $3.1^{\circ}$ at the $95 \%$ confidence level. An inclination of $-63^{\circ}$ is equivalent to a magnetic paleolatitude of $45^{\circ} \mathrm{S}$ and is shallower than the present inclination of $-73^{\circ}$.

\section{Site 749}

Seven samples were AF demagnetized, and 30 samples were thermally demagnetized at Site 749 . Two types of intensity decay curves during thermal demagnetization can be recognized similar to Site 747 . Examples of a demagnetization curve with two magnetic phases (Sample 120-749C-12R-4, $134-136 \mathrm{~cm}$ ) and one with one magnetic phase (Sample 120-749C-16R-5, 119-121 cm) are shown in Figures 4 and 5, respectively. The high-temperature phase may correspond to the magnetization of a Ti-poor titanomagnetite with ilmenite lamellae, and the low-temperature phase may correspond to titanomaghemite. Low-Ti titanomagnetite/maghemite grains with ilmenite lamellae crosscutting the grains were noted from microscopic observations, cell edge determinations, and Curie temperature measurements (Heider et al., this volume). The MDFs of eight samples range from 10 to $18 \mathrm{mT}$.

Except for one sample, all remaining samples from Site 749 have a stable remanent component during stepwise thermal or AF demagnetization. Sample 120-749C-15R-5, 73-75 cm, had an unstable direction, and its inclination changed considerably
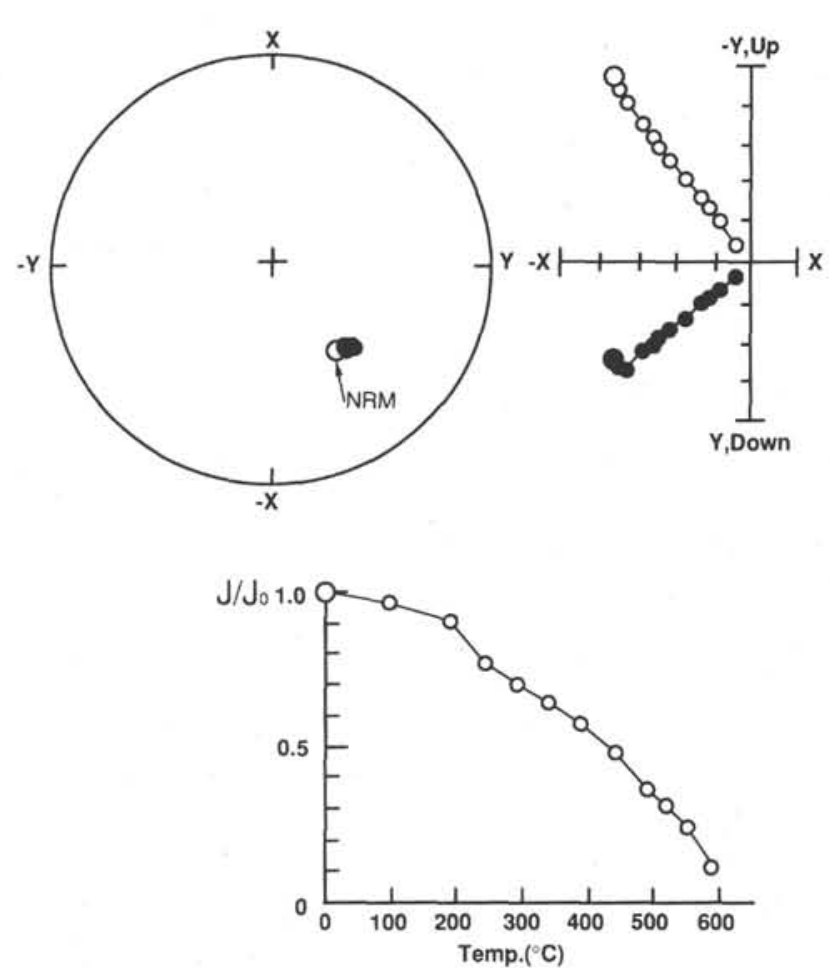

Figure 2. Thermal demagnetization of Sample 120-747C-15R-3, $127-$ $129 \mathrm{~cm}$. One magnetic phase is shown in the intensity decay curve and magnetization is stable. For an explanation of the diagrams, see Figure 1.
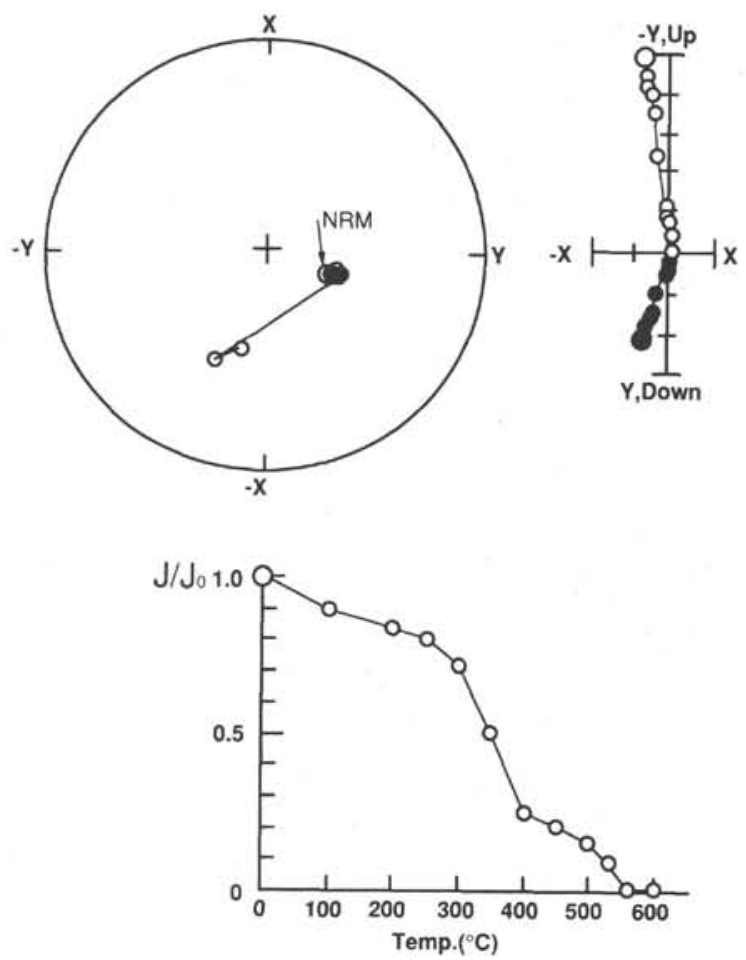

Figure 3. Thermal demagnetization of Sample 120-748C-79R-7, 3-5 $\mathrm{cm}$. Two magnetic phases are shown in the intensity decay curve and stable magnetization is obtained from the high-temperature component. 

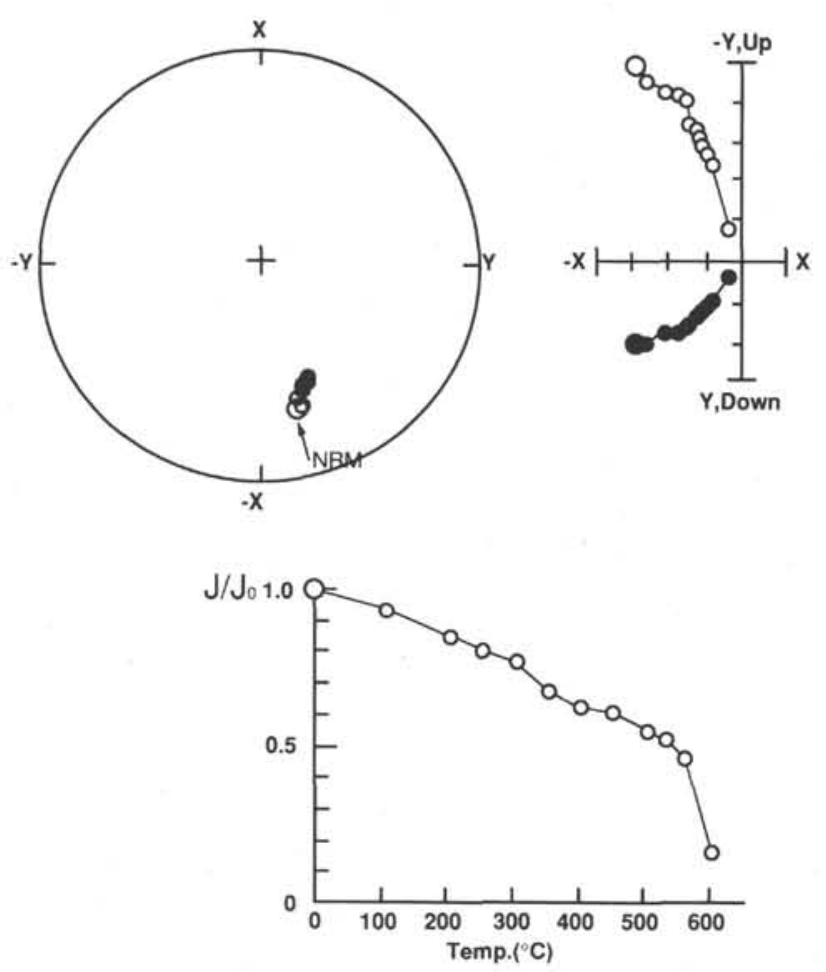

Figure 4. Thermal demagnetization of Sample 120-749C-12R-4, 134-136 $\mathrm{cm}$. Two magnetic phases are shown in the intensity decay curve, and stable magnetization is obtained from the high-temperature component.
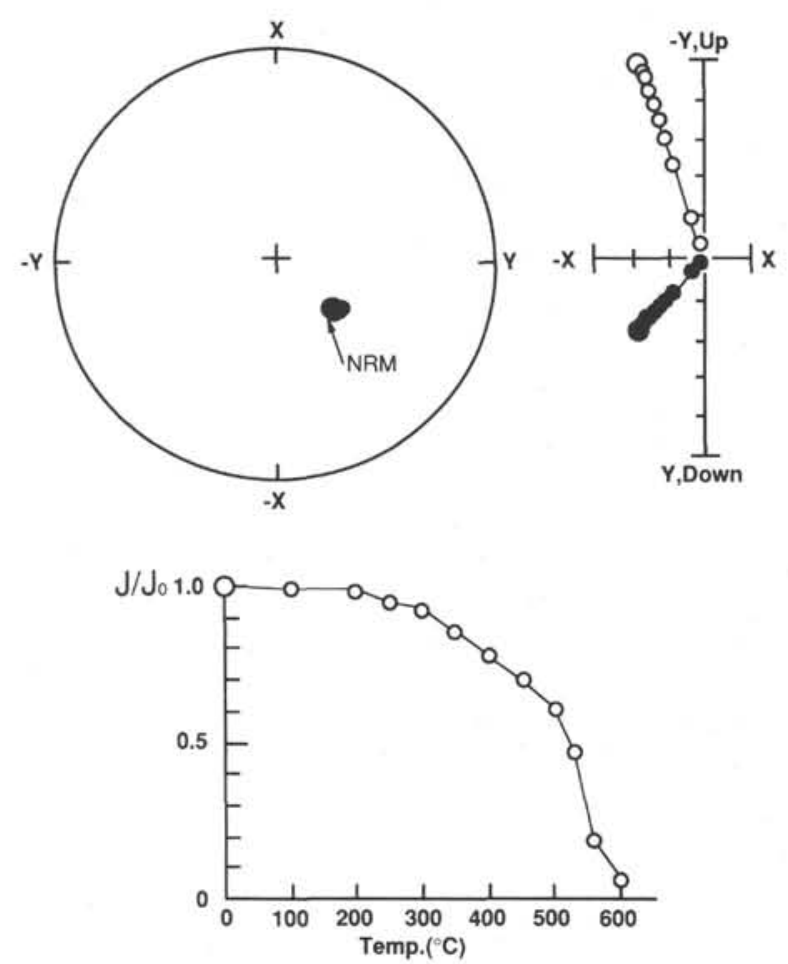

Figure 5. Thermal demagnetization of Sample 120-749C-16R-5, 119_ $121 \mathrm{~cm}$. One magnetic phase is shown in the intensity decay curve, and the magnetization is stable.
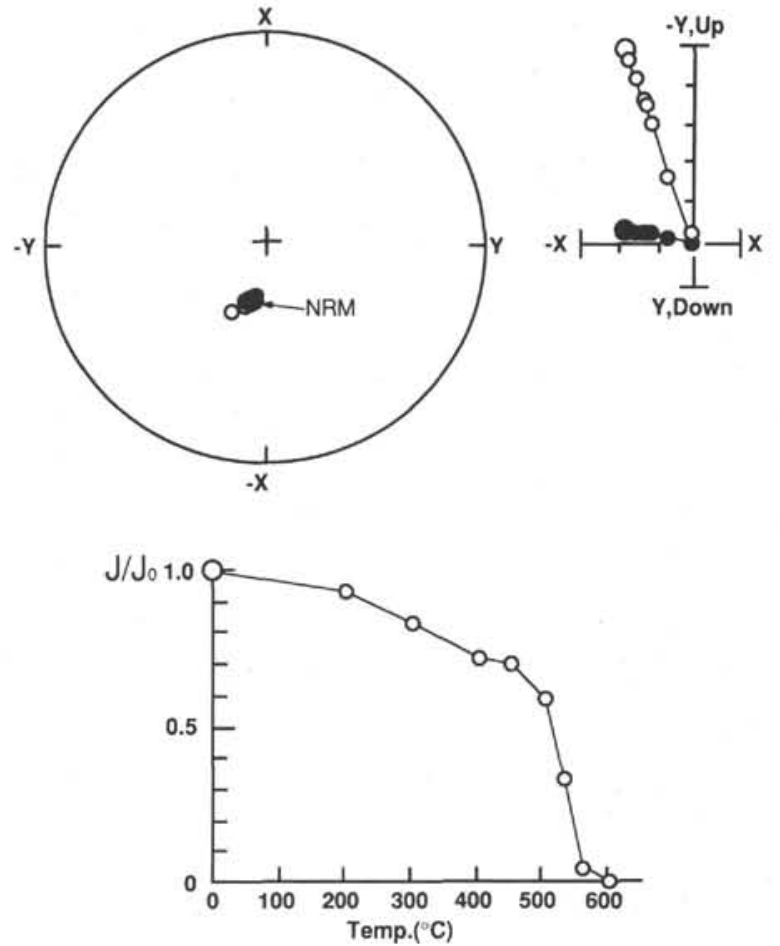

Figure 6. Thermal demagnetization of Sample 120-750B-15R-1, 62-64 $\mathrm{cm}$. One magnetic phase is shown in the intensity decay curve. The direction of magnetization remains stable during demagnetization.

during AF demagnetization. High-temperature oxidation of the basalts at Site 749 probably occurred during subaerial eruption (Schlich, Wise, et al., 1989). Therefore, the hightemperature oxidized magnetic mineral (magnetite with ilmenite lamellae) is expected to carry a characteristic inclination that is a primary magnetization. Characteristic inclinations from the same flow agree well among each other, as shown in Table 1. The mean inclination of each flow and their $95 \%$ confidence limit are shown in Table 1 . The mean inclination from five flows at Site 749 is $-62^{\circ}$, with an error of $4.0^{\circ}$ at the $95 \%$ confidence level. An inclination of $-62^{\circ}$ is equivalent to a magnetic paleolatitude of $43^{\circ} \mathrm{S}$ and is significantly different from the present inclination of $-73^{\circ}$.

\section{Site 750}

Six samples were AF demagnetized, and 27 samples were thermally demagnetized at Site 750 . Several samples from the top of the upper flow of the two flows and a sample from the bottom of the lower flow have a high-temperature component $\left(>500^{\circ} \mathrm{C}\right.$; Table 1$)$. The intensity ratio of the high-temperature component over the initial intensity varies among the samples. Two extreme examples of high (Sample 120-750B-15R-1, 62-64 cm) and low (Sample 120-750B$15 \mathrm{R}-4,25-27 \mathrm{~cm}$ ) intensity ratios are shown in Figures 6 and 7. More than half of the samples do not have a remanence component with an unblocking temperature above $500^{\circ} \mathrm{C}$, as shown in Figure 8 (Sample 120-750B-15R-5, 22-24 cm). Most samples without a high-T component do not have a stable magnetization and their characteristic inclinations cannot be determined. The MDFs of six AF demagnetized samples range from 4 to $17 \mathrm{mT}$.

Only about half of the samples from Site 750 have a stable remanence component during stepwise thermal or AF demag- 

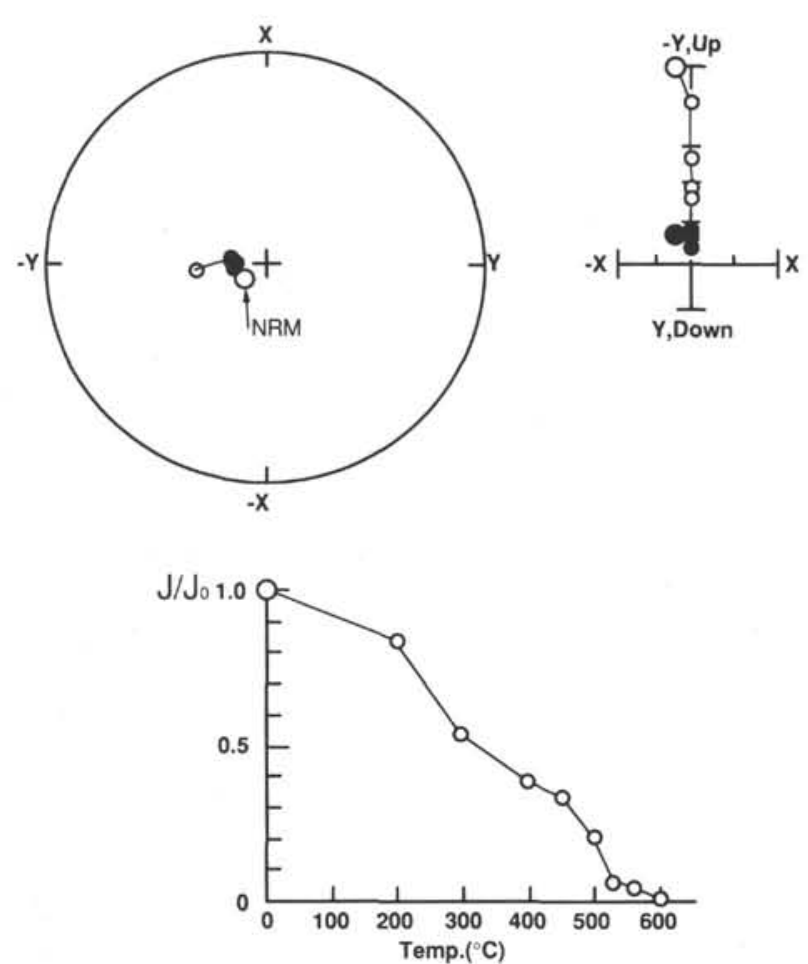

Figure 7. Thermal demagnetization of Sample 120-750B-15R-4, 25-27 $\mathrm{cm}$. Two magnetic phases are shown in the intensity decay curve. The stable component of magnetization is obtained from the high-temperature part of the decay.

netization. Characteristic inclinations from the same flow agree well among each other, as shown in Table 1 . The mean inclinations of the two flows are $-74^{\circ}$ and $-69^{\circ}$, and their $95 \%$ confidence limits are $1.7^{\circ}$ and $4.5^{\circ}$, respectively (Table 1 ). The mean inclination of Site 750 is calculated to be $-71^{\circ}$. An inclination of $-71^{\circ}$ is equivalent to a magnetic paleolatitude of $55^{\circ} \mathrm{S}$ and coincides within the error limits with the present inclination of $-72^{\circ}$ for Site 750 assuming a geocentric axial dipole.

The similarity of the paleomagnetic inclination and the present magnetic inclination at Site 750 strongly suggest a present field overprint caused by thermo-viscous or chemical magnetization. Low MDFs and the fact that approximately half of the samples have no stable remanent component suggest that the magnetizations of the samples from Site 750 are not reliable. Therefore, the results from this site will not be included in the further discussion of paleomagnetic directions.

\section{DISCUSSION}

The paleomagnetic results of the basalt samples from Site 747 through 750 of Leg 120 are summarized in Table 2. The mean values of the characteristic inclinations at each site are compared with the present inclinations, assuming a geocentric axial dipole. The paleolatitudes of the four sites are shown in relation to their present geographic latitudes.

Considerable differences between the paleomagnetic and present inclinations of Sites 747, 748, and 749 indicate that displacement in the direction of the geomagnetic meridian has taken place since formation of the basalt. Shallower paleomagnetic inclinations than the present inclinations at each site suggest southward movement of the sites.

One can detect tectonic movements between two tectonic blocks by comparing the apparent polar wander path (APWP)
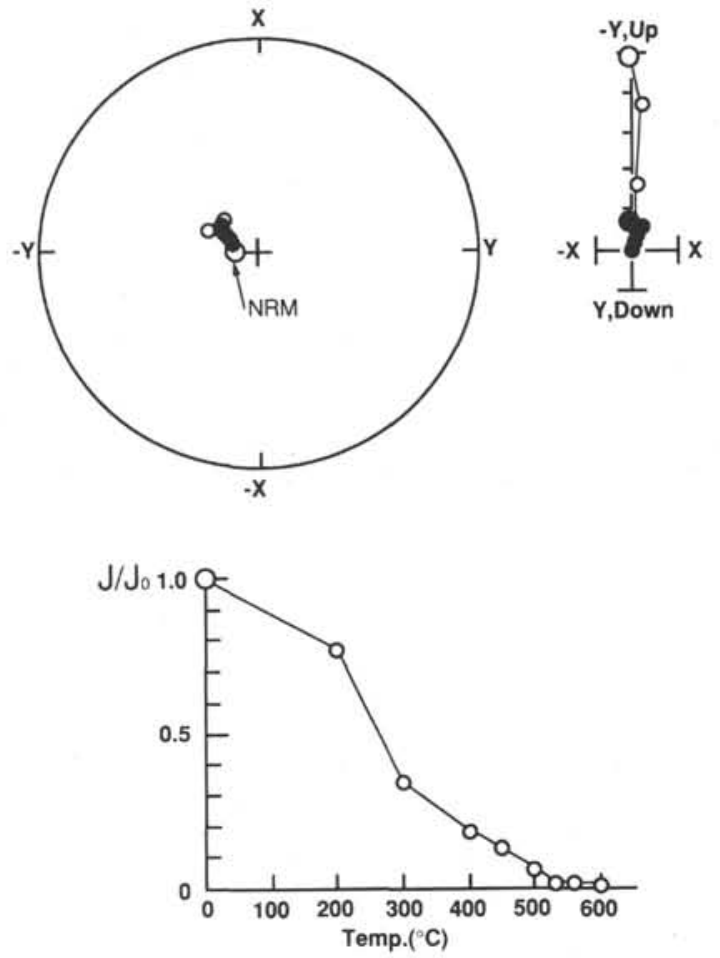

Figure 8. Thermal demagnetization of Sample 120-750B-15R-5, 22-24 $\mathrm{cm}$. No high-temperature components were observed. The magnetization is unstable.

Table 2. Summary of the paleomagnetic results of Sites 747, 748, 749, and 750 .

\begin{tabular}{lrrrr}
\hline \multicolumn{1}{c}{ Site } & 747 & 748 & 749 & 750 \\
\hline$N$ & 13 & 1 & 5 & 2 \\
Inc $(\mathrm{pm})\left({ }^{\circ}\right)$ & -51 & -63 & -62 & -71 \\
$\alpha_{95}\left({ }^{\circ}\right)$ & 7.3 & & 4.0 & \\
$k$ & 32 & & 353 & \\
Inc (pr) $\left({ }^{\circ}\right)$ & -71 & -73 & -73 & -72 \\
Paleolatitude $\left({ }^{\circ}\right.$ S) & 32 & 45 & 43 & 55 \\
Present latitude $\left({ }^{\circ} \mathrm{S}\right)$ & 55 & 58 & 59 & 58 \\
Inc $($ Ant) & & & & \\
a Upper Tertiary & -64 & -67 & -67 & \\
$\mathrm{~b}_{100 \mathrm{Ma}}$ & -61 & -64 & -64 & \\
${ }^{\mathrm{J} J u r a s s i c}$ & -41 & -46 & -45 & \\
Inc (Aus) ${ }^{\mathrm{a}}$ & & & & \\
$80 \mathrm{Ma}$ & -69 & -71 & -71 & \\
$100 \mathrm{Ma}$ & -68 & -70 & -69 & \\
$120 \mathrm{Ma}$ & -57 & -59 & -58 & \\
Inc (Ind) & & & & \\
$80 \mathrm{Ma}$ & -72 & -71 & -70 & \\
$100 \mathrm{Ma}$ & -69 & -68 & -68 & \\
$120 \mathrm{Ma}$ & -74 & -74 & -73 & \\
Inc (Afr) & & & & \\
$80 \mathrm{Ma}$ & -81 & -82 & -82 & \\
$100 \mathrm{Ma}$ & -82 & -82 & -83 & \\
$120 \mathrm{Ma}$ & -88 & -89 & -90 & \\
\hline
\end{tabular}

Notes: $N=$ number of flows; Inc (pm) = paleomagnetic mean inclination for each site; $\alpha_{95}=95 \%$ confidence limit; $k=$ precision parameter; Inc $(\mathrm{pr})$ $=$ present inclination in an axial dipole field. Paleolatitude was calculated from Inc (pm). Expected inclinations at each site from the APWPs for adjacent continents.

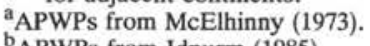

${ }^{\mathrm{b}}$ APWPs from Idnurm (1985).

${ }^{\mathrm{c}}$ APWPs from Piper (1987). 


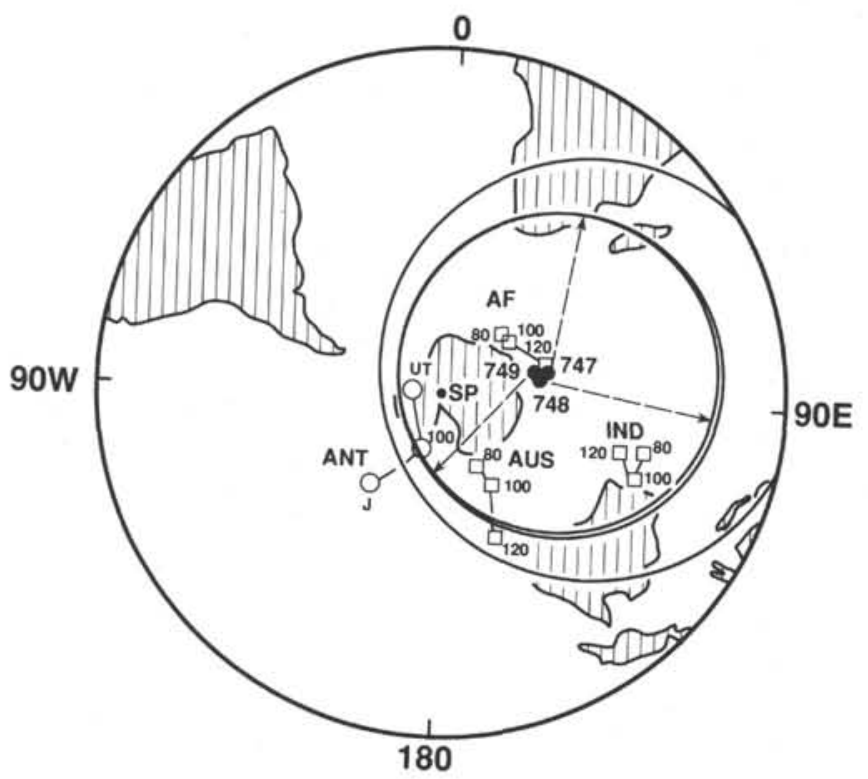

Figure 9. Positions (solid circles) of Sites 747, 748, and 749, and circles for their VGPs are shown in the equal angle projection. APWPs for Antarctica (ANT) during Upper Tertiary (UT) and Jurassic (J) (McElhinny, 1973) and at $100 \mathrm{Ma}$ (Idnurm, 1985) (open circle), Australia (AUS), India (IND) and Africa (AF) between 120 and 80 Ma (Piper, 1987) (open squares). VGPs for the Kerguelen Plateau fall on the APWP for Antarctica at about $100 \mathrm{Ma}$.

of one block (e.g., Antarctica) with the virtual geomagnetic pole (VGP) of the second block (e.g., Kerguelen Plateau). Unfortunately, only inclination data are available at the Kerguelen Plateau. The lack of declination data allows us to record only the drawing of circles for VGP positions, as shown in Figure 9. The APWPs of neighboring continents (i.e., Antarctica, Australia, India, and Africa) are plotted in Figure 9. The APWP for East Antarctica is only available for the upper Tertiary, Jurassic, and Cambro-Ordovician (McElhinny, 1973) and for a bias-corrected pole path from the Late Cretaceous to the present (Idnurm, 1985). The APWPs for Australia, India, and Africa are summarized by Piper (1987).

If no tectonic movement has taken place between the Southern Kerguelen Plateau (represented to a first approximation by Sites 747, 748, and 749) and one of the adjacent continents, then the VGP of the three sites should fall on the VGP of one of the continents at about $100 \mathrm{Ma}$. The age of basalts range from 100 to $115 \mathrm{Ma}$ (Schlich, Wise, et al., 1989, pp. 73-85, Fig. 4). The VGP circle of Site 747 intersects the APWP of Antarctica between the upper Tertiary and the Jurassic. The VGP circles of Sites 748 and 749 intersect the APWP of Antarctica in the same interval (Fig. 9). The VGP circles of Site 748 and 749 coincide with the bias-corrected VGP for Antarctica at $100 \mathrm{Ma}$, and they intersect the Australian APWP between 100 and $120 \mathrm{Ma}$.

Another way to detect tectonic displacements between two blocks is shown below using numerical values. By comparing inclinations obtained from poles on the APWP of one of the adjacent continents with the paleomagnetic inclinations for Sites 747,748 , and 749 , one can detect the displacements between the two blocks in the direction of the magnetic meridian. Based on the continental APWPs, inclinations that the continental rocks would be expected to have at the positions of the three sites can be calculated. These "imaginary" inclinations of the continents at Sites 747, 748, and 749 are shown in Table 2 at around $100 \mathrm{Ma}$. The paleomagnetic inclination $\left(-51^{\circ}\right)$ of Site 747 falls between the two inclinations expected for Antarctica in the Jurassic $\left(-41^{\circ}\right)$ and the upper Tertiary $\left(-64^{\circ}\right)$. The paleomagnetic inclinations of Sites 748 and $749\left(-63^{\circ}\right.$ and $-62^{\circ}$, respectively) fall between the twoinclinations expected for Antarctica in the Jurassic $\left(-46^{\circ}\right.$ and $\left.-45^{\circ}\right)$ and the upper Tertiary $\left(-67^{\circ}\right.$ and $-67^{\circ}$ ). Equally well, the paleomagnetic inclinations of Sites 748 and 749 lie between the "virtual" inclination, which are expected for the Australian Plate for 120 and $100 \mathrm{Ma}$. The paleomagnetic inclinations for Sites 747,748 , and 749 do not agree with the virtual inclinations of Africa and India.

The first implication for the tectonic displacement is that no major latitudinal movement has taken place between the Southern Kerguelen Plateau and Antarctica and/or the Southern Kerguelen Plateau and Australia as shown in Figure 9 and Table 2. However, longitudinal movement cannot be detected from paleomagnetic data, and seafloor spreading is directed almost in longitudinal direction between the Southern Kerguelen Plateau and Australia along the Southeast Indian Ridge starting in the Eocene (Le Pichon and Heirtzler, 1968). The suggestion that the Southern Kerguelen Plateau and Australia did not move with respect to each other is not realistic therefore. Many authors (e.g., Royer and Sandwell, 1989; Veevers et al., 1985; Schlich, 1975, 1982; Liu et al., 1983; Cande and Mutter, 1982; Norton and Sclater, 1979; Weissel and Hayes, 1972; McKenzie and Sclater, 1971) have reconstructed the tectonic history of the Indian Ocean using plate tectonic theory. Their results did not permit any tectonic movement between the Kerguelen Plateau and the adjacent plates, except for the Antarctic Plate.

Finally, we conclude that no major tectonic movement has taken place between the Kerguelen Plateau and Antarctica since formation of the basalt (i.e., 100-115 Ma). For instance, the tectonic history reconstructed by Royer and Sandwell (1989) did not show major movement between the Southern Kerguelen Plateau and Antarctica. A more detailed polar wander path for Antarctica will help to refine the understanding of the relation between the Southern Kerguelen Plateau and Antarctica.

The intermediate paleolatitudes $\left(32^{\circ}, 45^{\circ}\right.$, and $\left.43^{\circ}\right)$ for Sites 747,748 , and 749 suggest a southward motion of the Southern Kerguelen Plateau since the formation of the basalts. In addition to this major tectonic motion, there is possible further information that can be extracted from paleolatitudes (Table $2)$. If one subtracts the present latitudinal difference $\left(3^{\circ}\right.$ or $\left.4^{\circ}\right)$ between Sites 747 and 748 or Sites 747 and 749 from their difference in paleolatitudes, one obtains a net difference in latitude of $10^{\circ}$ or $8^{\circ}$. There are three possible explanations for this $10^{\circ}$ or $8^{\circ}$ difference.

The first possibility is that the paleolatitudes from Sites 747 and 748 or 747 and 749 are either similar or the same, which cannot be excluded based on the $95 \%$ confidence limit of the inclinations (Table 2). The second possible explanation could be dipping reflectors (see Schlich, Wise, et al., 1989, "Seismic Stratigraphy" section, "Site 747" chapter). Based on multichannel seismic reflection data, M. Coffin (pers. comm., 1990) estimates the dip of the layering within the basement at Site 747 as at least $10^{\circ}$ to the north and almost flat at Sites 748, 749, and 750 . If the basalt layers at Site 747 dip to the north at about $10^{\circ}$ because of tilting after deposition of the basement, the paleolatitudinal difference between the two groups of sites could be explained. Models of volcanic passive margin formation (Hinz, 1981; Mutter et al., 1982) suggest that the dip is acquired after the rocks are emplaced and have passed through the Curie temperature. This implies little $\left(5^{\circ}\right)$ or no tectonic displacement following emplacement of the basalt at Sites 747, 748, and 749. The third possibility is that Site 747 and the southern sites (Sites 748 
and 749) belong to different tectonic blocks. Latitudinal displacement between Sites 747 and 749 are approximately $450 \mathrm{~km}$, and the Central Kerguelen Plateau (Site 747) may have moved in a north-south direction with respect to the Southern Kerguelen Plateau (Sites 748 and 749). Plate reconstructions for the region (Coffin and Royer, this volume) could account for some, but not all of the difference. According to the Coffin and Royer model, Site 747 was on the Australian Plate between 110 and $43 \mathrm{Ma}$. During the same interval, Sites 748 and 749 were on the Antarctic Plate. Latitudinal displacement between Sites 747 and 748/749 was considered to be on the order of a few hundred kilometers.

Short-term variations in the geomagnetic field involve directional changes, called secular variation. The angular dispersion of the geomagnetic field over long periods of time represents the aspect of geomagnetic secular variation most accessible to paleomagnetic measurements. From Site 747, 13 paleomagnetic directions were obtained. A sample of 13 is considered to be too small to calculate the angular dispersion.

In our study, incomplete paleomagnetic data (i.e., only inclination data are available) are not suitable for the calculation of angular dispersion. Unfortunately, it is very difficult to obtain paleomagnetic data on paleosecular variation during the Late Cretaceous in a high southern latitude locality like Site 747. Therefore, the angular dispersion data of Site 747 is important.

The precision parameter $k$ from the 13 field inclinations was calculated using Kono's (1980) statistics. According to equations 6, 9, and 10 in McElhinny and Merrill (1975), the angular dispersion SF for the VGP is calculated as $16.6^{\circ}$. The upper and lower $95 \%$ confidence limits for SF are calculated as $22.4^{\circ}$ and $13.2^{\circ}$ from Cox (1969). The VGP angular dispersion of $16.6^{\circ}$ agrees with the mean paleosecular variation of the last 5 m.y. at $30^{\circ}$ magnetic latitude (McElhinny and Merrill, 1975). The paleosecular variation during the Late Cretaceous is almost the same as that of the Holocene age (Piper, 1987). Thus, we concluded that SF $=16.6^{\circ}$ for the Late Cretaceous on the Kerguelen Plateau is reasonable number, although the number of flows studied at Site 747 is rather small.

\section{CONCLUSION}

Reliable paleomagnetic inclinations were obtained from Sites 747,748 , and 749 as $-51^{\circ},-63^{\circ}$, and $-62^{\circ}$, respectively. The unstable magnetizations of the rocks from Site 750 were considered unreliable. We obtained two magnetic phases in the intensity decay curves during stepwise thermal demagnetization at Sites $747,748,749$, and 750 . The high-temperature magnetic component was generally rather stable and is carried by a high-temperature oxidized magnetic phase (Ti-poor titanomagnetite with ilmenite lamellae).

Considerable differences between the paleomagnetic and present inclinations of Sites 747,748 , and 749 suggest that displacement in the direction of the geomagnetic meridian has taken place since formation of the basalt. Shallower paleomagnetic inclinations than the present inclinations at each site suggest a southward movement of the sites with respect to the geomagnetic pole. By comparing the APWPs for adjacent continents with the VGP circles of the Southern Kerguelen Plateau, we suggest that no major latitudinal tectonic movement has taken place between the Southern Kerguelen Plateau and Antarctica since the formation of the basalts (i.e., 100-115 Ma).

\section{ACKNOWLEDGMENTS}

Discussions with Millard Coffin and his comments to the paper were highly appreciated. Critical reviews by N. Opdyke and R. Van Der Voo are also appreciated. We thank the Ocean Research Institute, the University of Tokyo, and the Ocean Drilling Program for the opportunities to participate on Leg 120.

\section{REFERENCES}

Cande, S. C., and Mutter, J. C., 1982. A revised identification of the oldest sea-floor spreading anomalies between Australia and Antarctica. Earth Planet. Sci. Lett., 58:151-160.

Cox, A., 1969. Confidence limits for the precision parameter K. Geophys. J. E. Astron. Soc., 18:545-549.

Hinz, K., 1981. A hypothesis on terrestrial catastrophes-wedges of very thick oceanward dipping layers beneath passive continental margins-their origin and paleoenvironmental significance. Geol. Jahrb., E22:3-28.

Houtz, R. E., Hayes, D. E., and Markl, R. G., 1977. Kerguelen Plateau bathymetry, sediment distribution and crustal structure. Mar. Geol., 25:95-130.

Idnurm, M., 1985. Late Mesozoic and Cenozoic paleomagnetism of Australia-III. Bias-corrected pole paths for Australia, Antarctica and India. Geophys. J. R. Astron. Soc., 86:277-287.

Johnson, H. P., and Merrill, R. T., 1974. Low temperature oxidation of a single-domain magnetite. J. Geophys. Res., 79:5533-5534.

Kono, M., 1980. Statistics of paleomagnetic inclination data. $J$. Geophys. Res., 85:3878-3882.

Le Pichon, X., and Heirtzler, J. R., 1968. Magnetic anomalies in the Indian Ocean and sea floor spreading. J. Geophys. Res., 73:21012117.

Liu, C. S., Curray, J. R., and McDonald, J. M., 1983. New constraints on the tectonic evolution of the eastern Indian Ocean. Earth Planet. Sci. Lett., 65:331-342.

McElhinny, M. W., 1973. Paleomagnetism and Plate Tectonics: Cambridge (Cambridge Univ. Press).

McElhinny, M. W., and Merrill, R. T., 1975. Geomagnetic secular variation over the past 5 m.y. Rev. Geophys. Space Phys., 13:687-708.

Mckenzie, D. P., and Sclater, J. G., 1971. The evolution for the Early Cretaceous breakup of Gondwanaland off southwestern Australia. Mar. Geol., 26:41-48.

Marshall, M., and Cox, A., 1972. Magnetic changes in pillow basalts due to seafloor weathering. J. Geophys. Res., 77:6459-6469.

Mutter, J. C., Talwani, M., and Stoffa, P. L., 1982. Origin of seaward-dipping reflectors in oceanic crust off the Norwegian margin by "subaerial sea-floor spreading." Geology, 10:353-357.

Norton, I. O., and Sclater, J. G., 1979. A model for the evolution of the Indian Ocean and the breakup of Gondwanaland. J. Geophys. Res., 84:6803-6830.

Piper, J.D.A., 1987. Paleomagnetism and the Continental Crust: Milton Keynes (Open Univ. Press).

Royer, J. Y., and Sandwell, D. T., 1989. Evolution of the eastern Indian Ocean since the Late Cretaceous: constraints from GEOSAT altimetry. J. Geophys. Res., 94:13,755-13,782.

Schlich, R., 1975. Structure et âge de l'ocean Indien occidental. Mem. Hors-Ser. Soc. Geol. Fr., 6:1-103.

1982. The Indian Ocean, aseismic ridges, spreading centers and basins. In Nairn, A. E., and Stehli, F. G. (Eds.), The Indian Ocean (Vol. 6): The Ocean Basins and Margins: New York (Plenum), 55-147.

Schlich, R., Wise, S. W., Jr, et al., 1989. Proc. ODP, Init Repts., 120: College Station, TX (Ocean Drilling Program).

Veevers, J. J., Tayton, J. W., Johnson, B. D., and Hansen, L., 1985. Magnetic expression of the continent-ocean boundary between the western margin of Australia and the eastern Indian Ocean. $J$. Geophys., 56:106-120.

Weissel, J. K., and Hayes, D. E., 1972. Magnetic anomalies in the southeast Indian Ocean. In Hayes, D. E. (Ed.), Antarctic Oceanology (Vol. II): The Australian-New Zealand Sector. Antarct. Res. Ser., 19:165-196.

Zijderveld, J.D.A., 1967. A.C. demagnetization of rocks: analysis of results. In Collinson, D. W., Creer, K. M., and Runcorn, S. K. (Eds.), Methods in Paleomagnetism: Amsterdam (Elsevier).

Date of initial receipt: 20 February 1990

Date of acceptance: 28 November 1990

Ms 120B-129 